\title{
PENERAPAN MODEL NUMBERED HEADS TOGETHER PADA KOMPETENSI DASAR KEADAAN SOSIAL NEGARA-NEGARA TETANGGA PELAJARAN IPS DALAM MENINGKATKAN HASIL BELAJAR SISWA KELAS VI SD NEGERI 068008 KEC.MEDAN TUNTUNGAN
}

\author{
Tiorim Silaban*
}

Surel: tiorim@gmail.com

\begin{abstract}
The results showed that during the pre-test before the action was taken from 27 students, 4 students (14.81\%) fulfilled the study and 23 students $(85.18 \%)$ did not fulfill the learning completeness with an average value of 42.74 , then in Cycle I obtained an increase in class average value of 25.14 (from 42.74 up to 67.88), with student learning rates from 27 students as many as 16 students (59.25\%) who met study completeness and 11 students ( $40.74 \%)$ did not fulfill the learning completeness. In the second cycle, the average score of the class increased to 84.22 with the level of student learning from 27 students as many as 24 students (88.88\%) that met the mastery of learning and 3 students (11.11\%) did not complete. It can be said that in cycle II learning completeness increased by 16.34 (from 67.88 up to 84.22).

Keywords: Numbered Heads Together, Model, Learning Outcomes
\end{abstract}

\begin{abstract}
ABSTRAK
Hasil penelitian menunjukan pada saat pre tes sebelum dilakukan tindakan diperoleh dari 27 orang siswa, 4 siswa $(14,81 \%)$ memenuhi belajar dan 23 siswa $(85,18 \%)$ tidak memenuhi ketuntasan belajar dengan nilai rata-rata 42,74 , selanjutnya pada siklus I diperoleh nilai rata-rata kelas meningkatkan sebanyak 25,14 (dari 42,74 naik menjadi 67,88), dengan tingkat belajar siswa dari 27 orang siswa sebanyak 16 siswa $(59,25 \%)$ yang memenuhi ketuntasan belajar dan 11 siswa $(40,74 \%)$ tidak memenuhi ketuntasan belajar. Pada siklus II diperoleh nilai rata-rata kelas meningkat menjadi 84,22 dengan tingkat belajar siswa dari 27 orang siswa sebanyak 24 siswa $(88,88 \%)$ yang memenuhi ketuntasan belajar dan 3 siswa $(11,11 \%)$ tidak tuntas. dapat dikatakan pada siklus II ketuntasan belajar meningkat sebesar 16,34 (dari 67,88 naik menjadi 84,22).
\end{abstract}

Kata Kunci: Model Numbered Heads Together, Hasil Belajar

\section{PENDAHULUAN}

Berdasarkan observasi awal yang guru lakukan di Kelas VI SD Negeri $068008 \quad$ kec.Medan Tuntungan. khususnya dalam pelajaran IPS menunjukan bahwa interaksi pembelajaran dalam kelas masih berpusat pada guru dan masih menggunakan metode ceramah, tanya jawab serta tidak menggunakan media dalam proses belajar mengajar dan siswa begitu saja menerima informasi yang diberikan guru. Padahal keberhasilan siswa dalam belajar bergantung pada aktifitas belajar siswa selama proses belajar mengajar berlangsung.

Penggunaan model pembelajaran yang kurang tepat merupakan salah satu penyebab rendahnya hasil belajar siswa Kelas VI SD Negeri 068008 kec.Medan 
Tuntungan, khususnya pada mata pelajaran IPS. Maka dari itu, seorang guru harus mampu menyusun pembelajaran yang membuat siswa aktif dalam belajar.

Dari permasalahan di atas maka perlu adanya upaya perbaikan hasil belajar siswa, salah satunya dengan cara memilih model pembelajaran yang sesuai dengan materi yang disampaikan. Peneliti memilih model pembelajaran Numbered Heads Together. Model pembelajaran ini dapat memacu siswa dalam menelaah materi yang tercakup dalam suatu pelajaran dan pemahaman mereka terhadap isi pelajaran.

\section{METODE PENELITIAN}

Jenis penelitian yang dilakukan adalah penelitian tindakan kelas (PTK) yang bertujuan untuk memperbaiki dan meningkatkan hasil belajar dalam proses pembelajaran siswa pada pelajaran IPS dengan menerapkan model Numbered Heads Together di Kelas VI SD Negeri 068008 kec.Medan Tuntungan.

Penelitian dilakukan pada siswa

Kelas VI SD Negeri 068008 kec.Medan Tuntungan. Tahun Ajaran 2014/2015 dan waktu pelaksanaan Penelitian Tindakan Kelas pada semester ganjil Tahun Ajaran 2014/2015 selama 3 bulan.

Objek penelitian dalam penelitian tindakan Kelas VI ini adalah "Menggunakan model Numbered Heads Togetheruntuk meningkatkan hasil belajar siswa pada pelajaran IPS materi pokok keadaan sosial negara-negara tetangga".

\section{SIKLUS I}

Kegiatan yang dilakukan dalam tahap ini adalah:

- Menyusun rencana pembelajaran yang akan disampaikan kepada siswa.

- Mempersiapkan materi ajar dengan pokok bahasan keadaan sosial negara-negara tetangga.

- Merancang pembagian beberapa kelompok.

- Mempersiapkan media pembelajaran yang sesuai dengan materi pembelajaran.

- Membuat lembar observasi aktivitas guru dan siswa dalam pembelajaran.

- Menyusun alat test/soal yang akan diberikan pada siswa berdasarkan kompetensi dasar yang dipelajari.

Pada tahap ini kegiatan yang dilaksanakan yaitu:

- Guru menyampaikan tujuan pembelajaran dan menjelaskan materi keadaan sosial negaranegara tetangga.

- Guru membagi siswa dalam beberapa kelompok yang beranggotakan 3-5 orang dan kepada setiap anggota kelompok diberi nomor 1 sampai 5.

- Guru memberi soal dan masingmasing kelompok mengerjakannya.

- Siswa menyatukan pendapatnya terhadap jawaban pertanyaan itu dan memastikan tiap anggota mengetahui jawaban tersebut. 
ESJ VOLUME 8, NO. 3, DESEMBER 2018

- Guru memanggil salah satu nomor, siswa dengan nomor yang dipanggil melaporkan hasil kerjasama mereka.

- Kelompok lain diberikan kesempatan untuk menanggapi jawaban dari kelompok yang sudah mempersentasikan hasil diskusi

- Guru dan siswa menimpulkan hasil diskusi.

- Guru memberi penilaian kepada siswa/kelompok.

Observasi dilakukan terhadap aktifitas siswa dan kinerja guru selama pembelajaran model Numbered Heads Together (NHT) dalam pembelajaran IPS berlangsung.Pengamatan ini bertujuan untuk mengetahui kesesuaian tindakan dengan rencana yang telah disusun guru. Pada tahap ini kegiatan yang dilakukan adalah melakukan pengamatan terhadap guru dalam proses tindakan dan kegiatan belajar siswa serta mengamati kondisi dan situasi saat proses pembelajaran berlangsung.

\section{Refleksi}

Kegiatan refleksi dilakukan untuk melihat perkembangan pelaksanaan serta memperoleh kesimpulan dari tindakan siklus I yang telah dilakukan dan apabila pelaksanaan siklus I belum tuntas berdasarkan indikator keberhasilan dan perolehan data dari hasil pengamatan maka hasil refleksi ini kemudian digunakan sebagai dasar untuk tahap perencanan pada siklus II.

\section{SIKLUS II}

Kegiatan yang dilakukan dalam tahap ini adalah:

- Mengidentifikasi masalah yang muncul pada siklus I dan menetapkan alternatif pemecahan masalah.

- Menyusun rencana pembelajaran yang akan disampaikan kepada siswa.

- Menyiapkan waktu yang digunakan dalam menggunakan model Numbered Heads Together.

- Mempersiapkan media pembelajaran yang sesuai dengan materi pembelajaran.

- Membuat lembar observasi aktivitas guru dan siswa dalam pembelajaran.

- Menyusun alat evaluasi/soal yang akan diberikan pada siswa berdasarkan kompetensi dasar yang dipelajari.

Pada tahap ini kegiatan yang dilaksanakan yaitu:

- Guru menyampaikan tujuan pembelajaran dan menjelaskan materi keadaan sosial negaranegara tetangga.

- Guru membagi siswa dalam beberapa kelompok yang beranggotakan 3-5 orang dan kepada setiap anggota kelompok diberi nomor 1 sampai 5 .

- Guru memberi soal dan masingmasing kelompok mengerjakannya.

- Siswa menyatukan pendapatnya terhadap jawaban 
pertanyaan itu dan memastikan tiap anggota mengetahui jawaban tersebut.

- Guru memanggil salah satu nomor, siswa dengan nomor yang dipanggil melaporkan hasil kerjasama mereka.

- Kelompok lain diberikan kesempatan untuk menanggapi jawaban dari kelompok yang sudah mempersentasikan hasil diskusi

- Guru dan siswa menyimpulkan hasil diskusi.

- Guru memberi penilaian kepada siswa/kelompok.

Observasi dilakukan terhadap aktifitas siswa dan kinerja guru selama pembelajaran model Numbered Heads Together dalam pelajaran

Refleksi

Kegiatan refleksi dilakukan untuk pengambilan kesimpulan terhadap seluruh aktivitas kegiatan siswa selama proses pembelajaran berlangsung. Jika pada tahap siklus II ini masih ditemukan bahwa siswa belum mampu menyelesaikan soalsoal dengan baik dan benar maka dilaksanakan siklus selanjutnya, namun jika telah memenuhi indikator keberhasilan yang ditetapkan maka tidak perlu dilakukan tindakan pada siklus selanjutnya, dengan kata lain pembelajaran dianggap selesai dengan hasil bahwa siswa telah memahami materi dan menyelesaikan soal-soal sudah tuntas.
HASIL DAN PEMBAHASAN

Berdasarkan kesulitankesulitan yang dihadapi siswa maka guru membuat alternatif pemecahan masalah, yaitu dengan menggunakan model pembelajaran Numbered Heads Together, yaitu dengan cara menyusun rencana pelaksanaan pembelajaran kemudian mempersiapkan materi ajar dengan pokok bahasan keadaan sosial negaranegara tetangga, merancang pembagian beberapa kelompok, mempersiapkan media pembelajaran yang sesuai dengan materi pembelajaran, membuat lembar observasi aktivitas guru dan siswa dalam pembelajaran, menyusun alat test/soal yang akan diberikan pada siswa berdasarkankompetensi dasar yang dipelajari.

Pada tahap ini guru menerapkan model pembelajaran Numbered Heads Together. Pelaksanaan tindakan pada siklus I ini dilakukan sebanyak dua kali pertemuan. Tiap pertemuan berlangsung selama dua jam pelajaran ( 2 x 35 menit). Pada tahap ini peneliti melaksanakan kegiatan pembelajaran yang merupakan pengembangan dan pelaksanaan dari program pengajaran yang disusun pada tahap perencanaan yaitu guru menjelaskan tentang materi keadaan sosial negara-negara tetangga, guru membagi siswa kedalam kelompok kecil dan setiap anggota kelompok diberi nomor, guru mengajukan pertanyaan kepada siswa dan guru member kesempatan kepada siswa untuk menyatukan pendapatnya kemudian beberapa siswa dengan 
nomor yang dipanggil melaporkan hasil kerjasama mereka kedepan. Kemudian guru memberikan kesempatan kepada kelompok lain untuk menanggapi jawaban dari kelompok yang sudah mempersentasikan hasil diskusi. Setelah itu guru dan siswa bersamasama menyimpulkan materi pelajaran yang telah dipelajari.

Setelah pelaksanaan siklus I selesai, guru memberikan pos test (tes hasil belajar I) dengan tujuan melihat hasil belajar siswa yang telah diberikan tindakan dan guna mengetahui sudah sejauh mana pemahaman materi dan kemampuan siswa dalam menyelesaikan soal materi keadaan sosial negara-negara tetangga pada pelajaran IPS.

Pada saat yang bersamaan pula peneliti diobserver oleh guru kelas untuk mengetahui konsistensi dalam melaksanakan pembelajaran dengan model pembelajaran Numbered Heads Together pada materi keadaan sosial negara-negara tetangga. Observer memberikan hasil bahwa kemampuan peneliti dalam memberikan materi dengan media gambar sebagai berikut:

Berdasarkan hasil observasi yang dilakukan selama proses belajar mengajar yaitu didapat:
$N O=\frac{S O}{S M} x 100 \quad$ maka $N O=\frac{47}{68} x 100=69,11($ Sudjana

Nana, 2009:133) dengan demikian hasil observasi tergolong dalam kategori cukup. Hanya saja pada penggunaan pendekatan kontekstual yang dilakukan guru kurang sesuai dengan kompetensi mengajar dan belum dilakukan secara sistematis, serta pemanfaatan waktu belum sesuai dengan yang diharapkan aktivitas siswa dalam mengikuti pembelajaran dengan menggunakan model Numbered Heads Together tergolong baik dengan nilai rata-rata yang diperoleh siswa secara klasikal 60,99 . Dengan demikian maka pada siklus II diharapkan aktivitas siswa akan lebih baik lagi dalam mengikuti pembelajaran dengan model Numbered Heads Togethersehingga diharapkan akan meningkatkan hasil belajar siswa pada materi keadaan sosial negara-negara tetangga.

Berdasarkan hasil tes berupa tugas menyelesaikan soal tentang membentuk organisasi kelas setelah dilakukan tindakan I pada siswa melalui penggunaan metode pembelajaran inkuiri didapat data sebagai berikut: 
Tiorim: Penerapan Model....

Tabel 4.6 Persentase Nilai Siklus I Siswa

\begin{tabular}{cccc}
\hline Nilai & F & Persentase \% & Keterangan \\
\hline $\mathbf{3 3}$ & 2 & $7,40 \%$ & Tidak Tuntas \\
\hline $\mathbf{4 7}$ & 4 & $14,81 \%$ & Tidak Tuntas \\
\hline $\mathbf{6 0}$ & 5 & $18,51 \%$ & Tidak Tuntas \\
\hline $\mathbf{7 3}$ & 9 & $33,33 \%$ & Tuntas \\
\hline $\mathbf{8 7}$ & 6 & $22,22 \%$ & Tuntas \\
\hline $\mathbf{1 0 0}$ & 1 & $3,70 \%$ & Tuntas \\
\hline & Jumlah nilai & $\mathbf{1 8 3 3}$ \\
\hline & Jumlah Siswa & $\mathbf{2 7}$ \\
\hline & Rata-rata nilai & $\mathbf{6 7 , 8 8}$ \\
\hline
\end{tabular}

Pada tabel 4.6 di atas maka dapat dinyatakan bahwa kemampuan siswa dalam memahami materi keadaan sosial negara-negara tetangga sudah baik. Diketahui bahwa nilai siklus I dari 27 orang siswa, 16 orang siswa yang mencapai tingkat ketuntasan belajar, sedangkan 11 orang siswa belum mencapai tingkat ketuntasan belajar.

Dari hasil post test I diperoleh tingkat ketuntasan belajar siswa secara klasikal dapat dihitung dengan rumus

$P K K=\frac{\sum \text { Siswa yang tuntas }}{\sum \text { Siswa }} \times 100 \%$

adalah $\quad \frac{16}{27} \times 100 \%=59,25 \%$

sedangkan siswa yang belum memenuhi ketuntasan adalah $\frac{11}{27} \times 100 \%=40,74 \%$.Dengan

demikian dari hasil pretest dan post test I diperoleh peningkatan persentase ketuntasan belajar secara kalsikal sebesar 44,44\%. Selanjutnya hasil post test I digunakan sebagai bahan acuan dalam memberikan tindakan pada siklus II guna mengatasi kesulitan-kesulitan yang dialami siswa dalam menyelesaikan soal-soal materi keadaan sosial negara-negara tetangga.

Dari post test I diperoleh kesulitan yang dialami siswa yaitu: 1) Siswa kurang mengerti dengan model pembelajaran Numbered Heads Together. 2) Banyaknya siswa yang bermain-main saat melakukan diskusi kelompok, dan siswa kurang aktif selama proses belajar mengajar. 3) Siswa mengalami kesulitan dalam memahami materi keadaan sosial negara-negara tetangga. 4) Siswa kurang teliti dalam mengerjakan soalsoal multiple choise (pilihan berganda).

Berdasarkan ketuntasan belajar siswa tersebut diperoleh persentase ketuntasan klasikal sebesar $59,25 \%$ atau 16 orang siswa. Pada siklus I ini terjadi peningkatan hasil belajar siswa sebesar 44,44\% dari pretest sebelumnya. Walaupun demikian keberhasilan proses belajar mengajar pada siklus I secara klasikal belum tercapai. Oleh karena itu perlu dilakukan perbaikan pembelajaran yang diharapkan dapat meningkatkan 
hasil belajar siswa maka dilanjutkan dengan pelaksanaan siklus II.

Siklus II dilaksanakan karena aktifitas dan hasil belajar siswa masih rendah pada siklus I. Pada siklus II, upaya yang dilakukan adalah mengoptimalakan pembelajaran dengan penerapan model pembelajaran Numbered Heads Together. Pada siklus ini, dilakukan tanya jawab antar kelompok dan memberikan kesempatan kepada siswa untuk melakukan kegiatan secara mandiri. Dalam diskusi kelompok guru harus sering memantau dan membimbing siswa dalam kelompok. Hal ini bertujuan untuk lebih mengaktifkan siswa di dalam kelompoknya dan siswa yang memiliki kemampuan lebih tinggi berusaha membantu siswa tersebut sehingga dapat mengerjakan soal dengan benar.

Pelaksanaan tindakan pada siklus II ini dilakukan sebanyak dua kali pertemuan. Tiap pertemuan berlangsung selama dua jam pelajaran ( 2 x 35 menit). Pada tahap ini peneliti melaksanakan kegiatan pembelajaran yang merupakan pengembangan dan pelaksanaan dari program pengajaran yang disusun pada tahap perencanaan yaitu guru menjelaskan tentang materi keadaan sosial negara-negara tetangga, guru membagi siswa kedalam kelompok kecil dan setiap anggota kelompok diberi nomor, guru mengajukan pertanyaan kepada siswa dan guru memberi kesempatan kepada siswa untuk menyatukan pendapatnya kemudian beberapa siswa dengan nomor yang dipanggil melaporkan hasil kerjasama mereka kedepan. Kemudian guru memberikan kesempatan kepada kelompok lain untuk menanggapi jawaban dari kelompok yang sudah mempersentasikan hasil diskusi. Setelah itu guru dan siswa bersamasama menyimpulkan materi pelajaran yang telah dipelajari.

Setelah pelaksanaan siklus II selesai, guru memberikan pos test (tes hasil belajar II) dengan tujuan melihat hasil belajar siswa yang telah diberikan tindakan dan guna mengetahui sudah sejauh mana pemahaman materi dan kemampuan siswa dalam menyelesaikan soal materi keadaan sosial negara-negara tetangga pada pelajaran IPS.

Berdasarkan hasil observasi yang dilakukan selama proses belajar mengajar yaitu didapat: $N O=\frac{S O i}{S M} x 100 \quad$ maka $N O=\frac{62}{68} x 100=91,17($ Sudjana

Nana, 2009:133) dengan demikian hasil observasi tergolong dalam kategori sangat baik. Artinya proses belajar mengajar dengan menggunakan model Numbered Heads Together sudah dijalankan secara maksimal.

Dari hasil observasi yang dilakukan, diketahui bahwa aktivitas siswa dalam mengikuti pembelajaran dengan menggunakan model Numbered Heads Together sangat baik dengan nilai rata-rata yang diperoleh siswa secara klasikal 82,16. Dengan demikian, peneliti menyimpulkan bahwa hasil belajar 
siswa dari aspek afektif dan psikomotornya pada materi keadaan sosial negara-negara tetangga akan lebih baik ketika mengikuti pembelajaran dengan model Numberde Heads Together. Berdasarkan hasil observasi pada siklus II, peneliti berupaya mempertahankan dan meningkatkan proses belajar mengajar dengan model pembelajaran Numbered Heads Together. Peneliti telah berhasil memotivasi siswa yang mengalami kesulitan dalam mengerjakan soal-soal serta siswa sudah memahami materi keadaan sosial negara-negara tetangga.

Dari hasil analisis yang dilakukan pada siklus II ini terjadi peningkatan sebesar 29,63\% dengan tingkat ketuntasan belajar siswa secara kaliskal sebesar $88,88 \%$. Hasil ini menunjukan bahwa tindakan pembelajaran dengan menggunakan model pembelajaran Numbered Heads Together dapat meningkatkan hasil belajar siswa dalam materi pokok bahasan keadaan sosial negaranegara tetangga. Dengan melihat hasil post test II dapat diketahui bahwa siswa telah mencapai ketuntasan belajar secara klasikal sehingga tidak perlu melakukan perbaikan tindakan lagi.

Berikut disajikan tabel peningkatan hasil belajar siswa pada pokok bahasan keadaan sosial negaranegara tetangga:
Tabel 4.12 Tabel Rata-Rata Hasil Belajar Siswa

\begin{tabular}{ccc}
\hline No & Jenis Tes & Rata-rata \\
\hline $\mathbf{1}$ & Pre Test & 42,74 \\
\hline $\mathbf{2}$ & Siklus I & 67,88 \\
\hline $\mathbf{3}$ & Siklus II & 84,22 \\
\hline
\end{tabular}

Tabel 4.13 Persentase Hasil Belajar Siswa

\begin{tabular}{ccc}
\hline No & Jenis Tes & Persentase (\%) \\
\hline $\mathbf{1}$ & Pre Test & $14,81 \%$ \\
\hline $\mathbf{2}$ & Siklus I & $59,25 \%$ \\
\hline $\mathbf{3}$ & Siklus II & $88,88 \%$ \\
\hline
\end{tabular}

Berdasarkan hasil penelitian, pada pretest yang dilakukan terhadap 27 orang siswa terdapat sebanyak 23 orang $(85,18 \%)$ yang mendapat hasil belajar rendah (tidak tuntas) dan sebanyak 4 orang $(14,81 \%)$ yang termasuk dalam kategori tuntas dalam belajar. Berdasarkan hasil penelitian ini, dapat dikatakan pretest yang diberikan peneliti kepada siswa menunjukan bahwa tingkat keberhasilan siswa pada materi keadaan sosial negara-negara tetangga tergolong rendah Oleh karena itu data hasil temuan ini dapat dijadikan acuan untuk melakukan tindakan dengan menggunakan model pembelajaran Numbered Heads Together. Setelah pemberian tindakan melalui pembelajaran Numbered Heads Together pada siklus I terdapat 11 orang $(40,74 \%)$ siswa yang belum tuntas dalam pembelajaran dan 16 orang $(59,25 \%)$ siswa ang tuntas dalam pembelajaran. Ini menunjukan terjadi peningkatan sebesar $44,44 \%$ dari hasil tes sebelumnya. Kesulitan yang dialami siswa pada siklus ini yaitu: 1) Siswa kurang mengerti dengan model pembelajaran Numbered Heads Together. 2) 
Banyaknya siswa yang bermain-main saat melakukan diskusi kelompok, dan siswa kurang aktif selama proses belajar mengajar. 3) Siswa mengalami kesulitan dalam memahami materi keadaan sosial negara-negara tetangga. 4) Siswa kurang teliti dalam mengerjakan soalsoal multiple choise (pilihan berganda).

Upaya yang dilakukan peneliti untuk mengatasi kesulitan dalam PBM agar hasil belajar lebih meningkat yaitu pada siklus II dilakukan tanya jawab dalam diskusi kelompok dan memberikan kesempatan kepada siswa untuk mengeluarkan pendapatnya. Hal ini bertujuan untuk lebih mengaktifkan siswa dan saling membantu dalam kelompok. Guru juga memotivasi siswa dan melibatkan siswa dalam pembejaran. Dengan cara ini materi yang diajarkan lebih mudah dipahami.

Dari hasil belajar ang diperoleh siswa pada siklus II, terdapat sebanyak 3 orang $(11,11 \%)$ siswa yang tidak tuntas dalam belajar sedangkan 24 orang $(88,88 \%)$ siswa yang termaksud kedalam kategori tuntas. Jika dibandingkan pada siklus I terjadi peningkatan sebesar $29,63 \%$. Dengan demikian dapat dikatakan bahwa siswa dapat memahami materi keadaan sosial negara-negara tetangga. Hal ini dapat dilihat dari hasil belajar siswa pada siklus II sebesar $88,88 \%$.

\section{SIMPULAN}

Setelah kita membahas beberapa hal, baik yang berupa teori maupun yang berupa temuan hasil dari lapangan, maka dalam bagian ini tibalah saatnya peneliti untuk mengambil suatu kesimpulan yang barang kali bisa kita gunakan untuk mengemukakan suatu saran, guna meningkatkan kualitas pendidikan terutama pendidikan IPS. Beberapa kesimpulan yang dapat ditarik dari hasil penelitian ini adalah:

1. Pada pre tes dari 27 orang siswa Kelas VI SD Negeri 068008 kec.Medan Tuntungan.terdapat 4 siswa yang tergolong tuntas dengan $\mathrm{PKK=}$ $\frac{4}{27} \times 100 \%=14,81 \%$ dan 23 siswa $\mathrm{PKK}=\frac{23}{27} \times 100 \%=85,18 \%$ siswa yang tergolong tidak tuntas.

2. Pada siklus I hasil yang dicapai tidak sesuai dengan target ketercapaian nilai, dari 27 orang siswa kelas VI SD Negeri 060931 Medan Kota.terdapat 16 siswa yang tergolong tuntas dengan $\mathrm{PKK}=\frac{16}{27} \times 100 \%=59,25 \%$ dan 11 siswa yang tergolong tidak tuntas

$\mathrm{PKK}=$ $\frac{11}{27} \times 100 \%=40,74 \%$. Tedapat $44,44 \%$ dari pretes $14,81 \%$ sampai siklus I 59,25\%, maka perlu dilanjutkan penelitian pada siklus II.

3. Pada siklus II hasil yang diperoleh sudah sangat menggembirakan 
dan sudah mencapai nilai yang ditargetkan. Nilai yang diperoleh pada siklus II adalah 24 orang siswa sudah mencapai pada kategori sangat baik dengan $\mathrm{PKK}=2 \frac{4}{27} \times 100 \%=88,88 \%$ dan 3 orang siswa yang termaksud pada kategori cukup yaitu dengan $\mathrm{PKK}=\frac{3}{27} \times 100 \%=11,11 \%$ yang masih tergolong rendah. Setelah diadakan penelitian, siswa yang rendah ini lambat menerima pelajaran, jadi pembelajaran yang dilakukan hanya sampai kepada siklus II.

4. Selanjutnya dari hasil data observasi pada siklus I kegiatan guru dalam mengajar diperoleh nilai rata-rata = $\frac{47}{68} \times 100 \%=69,11$ dan kegiatan siswa selama mengikuti pembelajaran memperoleh nilai rata-rata $=\frac{28}{44} \times 100 \%=63,6 \%$ termaksud kategori cukup, umtuk itu perlu dilanjutkan kembali observasi pada siklus II.

5. Ternyata terjadi peningkatan dimana kegiatan guru dalam mengajar pada siklus II memperoleh nilai rata-rata= $\frac{62}{68} \times 100 \%=91,17$ dan kegiatan siswa selama mengikuti pelajaran memperoleh nilai rata-rata= $\frac{39}{44} \times 100 \%=88,6 \%$ termaksud kategori sangat baik.

\section{DAFTAR RUJUKAN}

AM, Sardiman. 2011. Interaksi dan Motivasi Belajar-Mengajar. Jakarta: Raja Grafindo Persada.

Arikunto, Suharsimi, dkk. 2010. Penelitian Tindakan Kelas. Jakarta: BumiAksara.

Aqib, Zainal. 2011. Penelitian Tindakan Kelas. Bandung: CV. Yrama Widya.

Dimyanti. 2009. Belajar dan Pembelajaran. Jakarta: Rineka Cipta.

Huda, Miftahul. 2011. Cooperative learnin.

Yogyakarta:PustakaBelajar.

Istarani. 2011. 58 Model

Pembelajaran Inovatif. Medan: ISCOM Medan.

Purwanto. 2009. Evaluasi Hasil Belajar. Yogyakarta: Pustaka Pelajar.

Sapriya. 2009. Pendidikan IPS.

Bandung: PT

RemajaRosdakarya.

Slameto. 2010. Belajar dan FaktorFaktor yang Mempengaruhinya. Jakarta: Rineka Cipta.

Suprijono, Agus. 2010. Cooperative Learning. Surabaya: Pustaka Pelajar. 